Ms Sontag's sentiments are admirable and are eloquently expressed. But her points have already been made hundreds of times over the past few years - the whole book evokes a wearying sense of déjà $v u$. And Ms Sontag fails to get off her intellectual high horse, and descend to nitty-gritty practical problems. If metaphor is duplicitous, if we must stop using 'military metaphors' such as 'fighting disease', how on Earth are medical educators to get their message across to the public? If (as she rightly emphasizes) fear and prejudice stigmatize sufferers, how are we to instil that salutary fear of infection which is necessary to encourage

\section{Burden of proof}

\section{Beverly E. Griffin}

AIDS: The HIV Myth. By Jad Adams. Macmillan, London/St Martin's Press, New York: 1989. Pp.244. £12.95, $\$ 16.95$.

"Pestilences have a way of recurring in the world; yet somehow we find it hard to believe in ones that crash down on our heads from the blue sky" (Albert Camus, The Plague). Camus was describing a fictional plague that originated from a dormant organism which arose unbidden in an Algerian town in the 1940s. Later, in an intriguing piece of prognostic fiction from the 1970s, an author called Russell Foreman produced The Ringway Virus which threatened the human race. (It was traced to a single outbreak in Australia and differed from all known viruses in its speed of spread and deadliness of action.) In the $1980 \mathrm{~s}$, the virus of the moment is undoubtedly HIV. The epidemic is AIDS. But is this a matter of cause and effect?

Jad Adams, a journalist with a claim to scientific respectability, has written a meticulously researched book whose title leaves little doubt about his answer to the question. The implication of the title is reinforced by inclusion of a foreword by Peter Duesberg, the most articulate of those who are sceptical that HIV is the cause of AIDS. Adams summarizes his conclusions thus: "my view, informed only by literature on the subject . . . is that HIV does not cause AIDS. Another pathogen .... is the causative agent. . We will find out whether HIV causes AIDS but I predict this will happen a long way into the future and few will emerge from the historical record with much distinction".

Here I have jumped from the title page to the end of the book. What lies in between are a number of highly readable chapters on the origin of AIDS and the syndrome itself, the four Hs (haemophiliacs, heroin users, homosexuals, safer lifestyles? Surely there must be good metaphors as well as bad, true ones as well as false. After all, we have to use language, and what speech is not (as one might say) 'infected' with metaphors?

Like so many intellectuals, Ms Sontag seems so lost in the web of words that she is in danger of having nothing useful to say about (what she finds an offensive metaphor) conquering disease in the real world.

Roy Porter, Wellcome Institute for the History of Medicine, London, is currently at the William Andrews Clark Memorial Library, 2520 Cimarron Street, Los Angeles, California 90018, USA. is also discussed in a further chapter entitled "Finance".

Many will say that this book is totally flawed. I will say it has minor flaws. Adams concentrates too forcefully on the extremes - HIV is or is not the cause of AIDS - and too little on the middle position wherein HIV is seen as a contributing factor to the disease(s) with other, as yet unidentified, cofactors also being required. (This is not fence-sitting there is a precedent for the involvement of a latent virus, the herpesvirus EBV in this case, together with cofactors in several human malignancies.) One could even hope that HIV is involved because, in the normal sense, it is a relatively non-infectious virus. Therefore changes in life-style and the use of safer blood products (for the five $\mathrm{Hs}$ and the potentially large 'at risk' African population) could result in a decline in the AIDS epidemic.

Adams also falls into the trap (following Duesberg) of assuming that the presence of HIV antibodies should in fact mean vaccination protection for the patient. Again, to quote from the EBV literature. increased viral antibody titres are used diagnostically to predict people at risk of developing EBV-associated diseases. Thus, not all viral antibodies can be deemed to be markers of protection. Finally, as one who works with young scientists and medical technicians, I regret, and in part strongly disagree with, Adams's cynical assessment of the 'scientific method'

These, however, are minor points. Adams has written a highly provocative but important book on a huge medical problem. It deserves to be read (even by Nobel committees). There must be many 'HIV = AIDS agnostics' who will feel a great sense of relief if this book frees them from the pressures of silence imposed by the establishment (including journalists and journals). It will surely lead to a scientifically healthier society if the burden of proof for HIV as a deadly pathogen is returned to where it belongs - to those who maintain that HIV causes AIDS - and others are allowed to pursue alternative approaches in the battle for eradication of the disease.

Beverly E. Griffin is Director of the Department of Virology, Royal Postgraduate Medical School. Hammersmith Hospital, Du Cane Road, London W12 ONN, UK. up all philosophical pretensions and has become a powerful business that shapes the mentality of its practitioners". Named scientists are the butt of Adams's invective as he draws attention to their abandonment of the scientific approach, acquisition of vested interests in the virus they champion and use of steam-roller tactics to silence any opposition. In "Virus Hunters" he reveals a Gallic bias. The AZT story, a medical trial that was neither anonymous nor completed but resulted in the release of a drug for AIDS treatment,
- AIDS: Profile of an Epidemic, recently published, is more specific in scope than the title implies, in that the contributors deal largely with AIDS in the Americas. The book has, however, been published with commendable speed; it contains a great deal of up-to-date information, much of it pertaining to South and Central America. Publisher is the Pan American Health Organization, whose publication centre is at 49 Sheridan Avenue, Albany, New York 12210 . Price is $\$ 30$, plus shipping and handling. A Spanish edition is also available. 